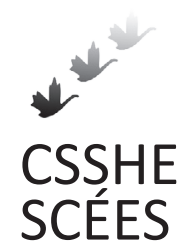

Canadian Journal of Higher Education Revue canadienne d'enseignement supérieur Volume 48, No. 1, 2018, pages 22 - 38

\title{
Working for a Living Wage Around the Ivory Tower
}

Andrew Stevens

University of Regina

\begin{abstract}
Since the 1980s, research on employment conditions in post-secondary institutions has focused on the growth of contingent academic workers, or what the Higher Education Quality Council of Ontario (HEQCO) has labelled "nonfull-time instructors" (Field, Jones, Stephenson, \& Khoyetsyan, 2014). Very little attention, however, has been paid to administrative, physical plant, and other operational staff employed within universities and colleges. Using data from a study of University of Regina students and employees, academic and support staff, this paper confronts the broader conditions of labour around the ivory tower. Employment at a post-secondary institution is analyzed through the lens of living wage research advanced by the Canadian Centre of Policy Alternatives (CCPA) (Ivanova \& Klein, 2015). The study reframes the notion of a living wage in a post-secondary institution to include work-life balance, job security, and the realities of dignity and respect in the university workplace.
\end{abstract}

\section{Résumé}

Depuis les années 1980, la recherche sur les conditions d'emploi dans les établissements postsecondaires a porté sur l'accroissement du nombre de travailleurs et travailleuses universitaires occasionnels ou de ceux que le Conseil ontarien de la qualité de l'enseignement supérieur (COQES) a qualifiés d' « enseignants non à temps plein » (Field, Jones, Stephenson, \& Khoyetsyan, 2014). Très peu d'attention a, toutefois, été accordée au personnel des services administratifs, du service des bâtiments et terrains et autres employés opérationnels dans les universités et collèges. S'appuyant sur les données d'une étude des étudiants et des employés, du personnel enseignant et de soutien de l'Université de Regina, l'article confronte les conditions générales de travail dans la tour d'ivoire. Il analyse l'emploi dans un établissement postsecondaire dans l'optique de la recherche sur le salaire vital avancée par le Centre canadien de politiques alternatives (CCPA) (Ivanova \& Klein, 
2015). L'étude reformule la notion de salaire vital dans un établissement postsecondaire pour inclure l'équilibre travail-vie personnelle, la garantie d'emploi et les réalités de la dignité et du respect au milieu universitaire.

\section{Introduction}

Since the 1980s, research on employment conditions in post-secondary institutions has focused on the growth of contingent academic workers, or what the Higher Education Quality Council of Ontario (HEQCO) has labelled "non-full-time instructors" (Field, Jones, Stephenson, \& Khoyetsyan, 2014). Corporatization, commodification, and the explosion in number of post-secondary managers have received equally impressive coverage in the academic literature (Noble, 2002; Polster \& Newson, 2015). Very little attention, however, has been paid to administrative, physical plant, and other operational support staff employed within universities and colleges. Indeed, their marginalization is twofold.

First, with the exception of senior managers, staff are typically excluded from collegial governance processes. As interview participants insisted, their marginalization is also a symptom of the perception that the function they serve is one of secondary support rather than advancing the core academic mission of the institution. With rare exception, this exclusion is maintained in the literature even as "non-academic" workforces are impacted by the neo-liberalization of post-secondary education through budget cuts and layoffs. As Isabelle Losinger (2016) writes, "University staff is often an afterthought, or more practically speaking, a non-thought” (p. 154). Here, Losinger laments that staff are characterized as the "non-non" and defined by what they do not do: non-academic, non-faculty, non-teaching, non-professional, and non-classified.

Using data from a study of University of Regina students and employees-academic and support staff-this paper confronts the broader conditions of labour around the ivory tower. Employment at a post-secondary institution is analyzed through the lens of living wage research advanced by the Canadian Centre for Policy Alternatives (CCPA) (Ivanova \& Klein, 2015). The CCPA's model has been adopted by employers and living wage networks across Canada, making it a meaningful benchmark through which to assess post-secondary employment. What frustrates "non-academic" and academic workers in this regard is that high-quality services are still maintained despite eroding conditions of work. Indeed, in workplaces where full-time and permanent employees typically earn living wages, an effective analysis of labour conditions requires an examination of other, non-compensatory factors and occupational inter-relationships. This is a part of the relational elements defining precarious employment within post-secondary institutions and the broader "proletarianization" of academic labour (Burns, 2014; Nelson \& Dobson, 2015; Palmer, 2013). A living wage framework is used to investigate these lived realities of work amongst the denizens of a post-secondary institution in Saskatchewan, including the students who struggle to cope with work, life, and education. Here, the study expands upon internationally recognized living wage methodologies (Parker, Arrowsmith, Fells, \& Prowse, 2016) to include an investigation of work-life balance, job security, and working conditions to more effectively examine the experiences of employment in and around the ivory tower through a survey of and interviews with students and staff. This approach is consistent with historical and contemporary definitions of "living wages," and it aligns with recent living wage literature that insists on considering what is meant by "living" beyond the focus on basic pay (Carr, Parker, Arrowsmith, \& Watters, 2016). 


\section{The "Living Wage"}

In the 19th century, English professor J.E.C. Monro defined a living wage as a "yearly wage sufficient to maintain the worker in the highest state of industrial efficiency and to afford him adequate leisure to discharge the duties of citizenship" (cited in "A living wage," 1894, p. 365). These reflections would certainly resonate with opponents and advocates of the living wage today. The living wage model advanced by the CCPA, for instance, reflects what people need to support themselves based on actual costs of living and not market measures governed by supply and demand (Ivanova \& Klein, 2015).

Legal scholar Harry Arthurs (2006) wrote in his review of Canada's labour standards regime that "no worker and by implication their family should receive a wage that is insufficient to live on...or be required to work so many hours that he or she is effectively denied a personal or civil life" (p. 47). Indeed, the social dimension of wages and wealth distribution has long been a concern for radicals and social reformers since the earliest periods of industrialization. Today's living wage movements initially surfaced in the $1990 \mathrm{os}$ following decades of real wage stagnation, just as labour's share of GDP in Canada and the United States shrank (Sharpe, Arsenault, \& Harrison, 2008; Government of Canada, 2013). Subcontracting, outsourcing, and the privatization of government enterprises and services amplify the problem for workers (Stevens, 2014). The casualization of employment positions and the deployment of limited term contracts in lieu of full-time, permanent jobs accompanies these tendencies. Such trends are certainly not alien to Canadian post-secondary institutions.

Beginning with a successful living wage campaign in Baltimore in 1994, living wage movements spread across the United States, the UK, and recently, Canada. The number of cities with living wage laws took off again in the recession and job-loss years of 2000 to 2003 (Fairris \& Reich, 2005). Estimates indicate there are around 140 living wage ordinances across the United States. Decades of research suggest that these movements enable community allies to rally around long-term economic justice, in addition to achieving wage and benefits increases for marginalized workers in the short term (Nissen, 2000; Wells, 2016). Campus living wage campaigns in the United States and Canada, meanwhile, have targeted the pay and working conditions of janitors and clerical staff, many of whom are non-unionized, at some of that country's most prestigious academic institutions. As Walsh (2000) recognizes, living wage campaigns emerged on American campuses throughout the late 1990s. Indeed, campus mobilizations tend to be broad coalitions involving students, academic staff, workers, community members, and faith groups. Dozens of post-secondary institutions across the UK and the United States, including the Ivy League universities, have since committed to paying a living wage (Flynn, 2012). Much of the theoretical and empirical findings have even emerged from participatory research agendas stemming from these movements (Ana \& Hall, 2015). In Canada, cleaning staff at McMaster University fought for and achieved a living wage through bargaining, despite threats of outsourcing during negotiations (Nolan, 2014). Faced with public support and a coalition of university staff and community members, the administration relented on its hardball tactics and announced it would offer a living wage to these workers (Wells, 2016).

Living wage campaigns have also been identified as a means of responding to a new landscape of work and capitalism through municipal ordinances, voluntary recognition schemes, or minimum wage increases. Modelled on the Fight for $\$ 15$ movement in the 
United States, Canada's Fight for $\$ 15$ and Fairness pushes for major increases in legislated minimum wage rates, among other employment standards benefits. Indeed, a consideration for work quality and the nature of employment is nested within the constellation of living wage projects. Privatization, subcontracting, amplified use of casual labour and internships, and the fragmentation of production and supply chains have further fuelled the significance of these movements. These practices, scholars argue, have allowed private and public sector employers to simultaneously shed responsibility and disempower the workforce (Wills, 2009). The proliferation of low-wage work is a symptom of such trends. Without these considerations, simply raising the floor of wages will not address the precarious nature of employment facing a growing number of workers (Luce, 2015).

Hours of work, work-life balance, and the number of jobs held by employees provide an impetus for living wage calculations. In real terms, it means that a living wage includes an income sufficient to participate in recreational and community activities, in addition to food, housing, and other basic needs embedded with Statistics Canada's Market Basket Measure (Ivanova \& Klein, 2015). The calculation is premised on a model of a four-person family with two children and two income-earning parents, each working 35 hours per week. Retirement savings, homeownership, and debt servicing costs are not included in the calculation. Living wage networks and policy advocacy groups from across Canada have adopted this methodology. A Saskatchewan-based study published by the CCPA for the city of Regina determined a living wage hourly wage to be $\$ 16.95$, or an annual household income of approximately \$61,000 (Canadian Centre for Policy Alternatives - Saskatchewan, 2016). Nearly a quarter of workers in Regina-where the University of Regina and its federated colleges are based-and about $41 \%$ of households earned less than a living income (Statistics Canada microdata; Statistics Canada, 2011).

\section{Living Wages and the Ivory Tower}

Non-full-time instructors are typically categorized into three broad groups: sessionals, who are employed on a per-course basis; graduate student instructors; and other instructors, a category that includes a range of appointments that are often difficult to compare across institutions (Field, Jones, Stephenson, \& Khoyetsyan, 2014). All of these classifications are characterized by their lack of employment security, and with such appointments comes the understanding that they are temporary (Baldwin, Chronister, Rivera, \& Bailey, 1993). Sessionals are indeed the quintessential "just-in-time" workers. This perception has led to characterization of the non-permanent lecturer as a form of migrant labour: inexpensive, temporary, and mobile (Mysyk, 2001). And while the use of temporary and non-tenured part-time faculty is a long-established tradition, what has changed is the extent to which this constituency has become a staple of university-level instruction (Warme \& Lundy, 1988). In this context Rajagopal (2002) argues that sessional positions are increasingly staffed by individuals who aspire to hold tenure-stream appointments but are unable to secure these coveted full-time appointments. This "contemporary" model compares to the historical use of "classic" contingent faculty, typically professionals who lend their expertise by teaching university classes. Both typologies of non-tenure track faculty offer benefits to universities by enabling institutions to preserve flexibility in a period of financial constraint and make it easy for administrators to respond quickly to enrolment patterns (Baldwin, Chronister, Rivera, \& Bailey, 1993). 
Although there is no central repository of statistics regarding part-time faculty, the consensus is that universities across Canada, the United States, the UK, and Australia are expanding the number of casual, non-permanent academic workers they employ (Field, Jones, Stephenson, \& Khoyetsyan, 2014; Standing, 2015). The lack of national or institution-level data on this category of university employees is, according to some, a reflection of the tenuous and ephemeral nature of their existence in academia (Muzzin, 2009). Virtually no data exist on administrative and other support function occupations that exist within the ivory tower. The existing evidence suggests that the casualization of academic labour has gone further in Canada than in the United States (Dobbie \& Robinson, 2008). Even as academic unions attempt to combat the growth of contingent labour through collective bargaining, it appears that unionization has done little to curb this trend, just as the university's research and education functions are increasingly subject to commodification (Mysyk, 2001; Noble, 2002; Noonan \& Coral, 2015). Contingent faculty appointments in this sense function as a response to soaring enrolments, increases in class sizes, tuition inflation, and the loss of tenured faculty to attrition, where sessionals are hired in their place. Conversations, such as this one, unfold as universities move from bastions of liberal arts education (Axelrod, Anisef, \& Lin, 2001) to audit-driven institutions (Spooner, 2017) and as spaces of and for commercialization (Pocklington, Tupper, \& Titley, 2002).

The losers in this process tend to be students who experience larger class sizes and amplified costs, along with the university workers who face job cuts, stagnant wages, and benefit cutbacks (Dobbie \& Robinson, 2008; Newson, 2015). These tendencies represent a game of "catch-up," where post-secondary employment converges with other corners of the market long defined by precarious work relations (Standing, 2011, 2015). Research points out that contingent workers are no longer secluded to the lower rungs of the labour market, but exist as highly educated and skilled professionals (Muzzin, 2009; Nelson \& Dobson, 2015). Accompanying this status are the stress, exhaustion, overwork, anxiety, ill health, and insecurity that typically define precarious employment (Gill, 2014). As evidence from my study of employment at the University of Regina illustrates, these characteristics have converged to include administrative and other support staff.

\section{Methods}

Containing a total of 60 branching questions, the online survey ran from September 2015 to February 2016 and addressed a range of issues, including demographics (sex, age, relationship status, country of origin, parental status), income, education status, employment, job security, job satisfaction, cost of living, and other related subjects. Survey questions were premised on campus living wage studies, specifically Flynn's (2012) research at Simon Fraser University, which examined compensation, working conditions, job security, and costs of living for "low-wage, contracted or auxiliary workers" employed at the university (p. 15). Similar research models have been deployed in living wage studies at UK universities, where issues related to workload, working conditions, and outsourcing were investigated alongside questions of pay and benefits (Ana \& Hall, 2015). My study involves a similar methodology, but goes on to include students and staff with the purpose of rendering a broader picture of employment amongst the population at a post-secondary institution. Invitations to participate in the study were distributed through various campus listservs, as well as promoted through posters, class and worksite visits, social media, and 
word of mouth. Because high-profile campus institutions like the Community Research Unit (CRU) and Regina Public Interest Research Group (RPIRG) supported the study, visibility was enhanced amongst students and staff. Unless stated otherwise, the use of "University of Regina" is meant to include the federated colleges (Luther College, Campion College, and First Nations University of Canada). A total of $687(n=687)$ members of the university community (students and staff) completed the survey. Table 1 provides a breakdown of survey participants by university occupation and median annual income ranges. Of that population, approximately 264 participants agreed to participate in a follow-up interview, but only 30 were ultimately selected. These individuals were then contacted and asked to complete a short survey with the purpose of constructing a representative interview sample. Semi-structured interview questions focused primarily on the respondent's economic history, employment information, childcare needs, parental status, as well as their opinions on living wages and employment, student experiences, and living wage policies.

Table 1.

Median annual income by occupation

\begin{tabular}{lcc}
\hline University employee occupation & $\begin{array}{c}\text { Number of respondents } \\
(n=324)\end{array}$ & $\begin{array}{c}\text { Median annual pre-tax } \\
\text { income range }\end{array}$ \\
\hline Academic staff (all categories) & 68 & $\$ 66,000-\$ 75,000$ \\
Teaching assistant & 47 & $\$ 11,000-\$ 20,999$ \\
Research assistant & 27 & $\$ 21$, ooo- $\$ 35,999$ \\
Research associate & 2 & $\$ 41,000-\$ 51,000$ \\
Administrative, professional, and & 90 & $\$ 66$, ooo- $\$ 75,999$ \\
$\quad$ technical (APT) & 43 & $\$ 46$, ooo- $\$ 55,999$ \\
Non-APT support staff & 4 & Below $\$ 10,999$ \\
Food services & 10 & $\$ 21,000-\$ 35,000$ \\
Co-op student & 6 & Over $\$ 100,000$ \\
Senior executive/manager & 17 & $\$ 16,000-\$ 26,000$ \\
Other & 5 & $\$ 11,000-\$ 20,999$ \\
Residence assistant & 5 & $\$ 21,000-\$ 35,999$ \\
Teaching fellow & &
\end{tabular}

\section{Work at This Ivory Tower}

Publicly available data indicate that, of the University of Regina's employment complement of 2,667 , about $54 \%$ (or 1,427) of employees are considered "term/casual," and about 46\% (or 1,240) are permanent (University of Regina, 2015b). Five labour organizations represent approximately 2,400 academic and non-academic workers at the various federated colleges, each of which has its own respective compensation and benefit structures. Some of the statistics below have been compiled using publicly accessible sources as well as figures acquired through various unions and campus employers. 
Spanning across seven bargaining units, the University of Regina Faculty Association (URFA) represents a diverse membership from the 355 administrative, professional, and technical (APT) staff to the 881 academic staff at the University of Regina, Campion College, Luther College, and First Nations University of Canada (FNUniv). About 1,00o of URFA's 1,200 members are employed at the University of Regina. Annual salaries average $\$ 114,153$ for the professorial ranks and about $\$ 74,000$ for APT employees across the University of Regina and federated colleges, well above existing living wage benchmarks. Wage inequities are maintained between the federated colleges. By comparison, senior managers at the University of Regina earn on average $\$ 163,330$ per year.

Canadian Union of Public Employees (CUPE) locals represent around 1,200 academic and non-academic support staff. This list includes teaching assistants (TAs), teaching fellows, research assistants (RAs), facilities management, operational staff, security personnel, trades, and applied scientific employees. Over $60 \%$ of these employees are considered term or casual employees. Food services on campus are provided by a range of unionized and non-unionized workers earning between $\$ 12$ and $\$ 21$ per hour, numbering between 70 and 80 casual, part-time, and full-time employees. Hourly rates of pay for TAs and RAs range from $\$ 13.93$ to $\$ 21.86$ based on student enrolment status (undergraduate, master's, $\mathrm{PhD}$ ), while semester-based stipends for these academic workers vary between $\$ 1,253$ and $\$ 2,469.83$. Teaching fellows are remunerated $\$ 6,623.69$ per course. The collective agreement representing these workers offers no supplemental benefits.

Hourly rates of compensation for support staff range from $\$ 13.17$ to $\$ 42.76$ based on seniority and occupation. Base monthly salaries vary from $\$ 2,209$ (35 hrs/week) to $\$ 7,041$ (38 hrs/week). Several hundred employees work at the university as non-unionized accompanists, consultants, co-op students, health centre workers, Elders, facilitators, postdoctoral fellows, and models, as well as project, writer, contract, research, and resident attendants. No consistent rates of pay exist for this diverse category of "other" employees.

Academic staff constitute the most term-based workforce at the university. If TAs, RAs, and teaching fellows are included, only a third of research and teaching-focused positions are permanent. Over 6o\% of academic workers hold term or casual appointments. Including the federated colleges, there are 509 academic positions at the University of Regina, up 5\% from 2012. This figure includes instructors, lab instructors, and librarians, as well as members of the professorial ranks (lecturer, assistant, associate, professor). The federated colleges do not maintain comprehensive data on sessional categories, which is a telling reflection on the status of these academic employees within the university community. Drawing from both the "contemporary" and "classical" camp of non-permanent academic staff positions articulated by Rajagopal (2002), there are no less than five sessional lecturer categories, ranging from conventional course instructors to practicum supervisors (University of Regina, 2015, p. 16).

Between 2011 and 2014, the number of sessional appointments at the University of Regina-excluding the federated colleges-went from 716 to 819 , representing a $12 \%$ increase. This growth occurred despite the university being obliged to "reduce the proportion of sessional appointments" in accordance with the URFA-University of Regina Academic Staff agreement. In 2014, there were nearly twice as many sessional appointments as permanent academic positions. Compensation structures also vary across sessional appointment types from a stipend of $\$ 7,063$ for each course to a sessional laboratory instructor who receives $\$ 93.60$ per hour. 


\section{Income and Precarious Work}

Over half of the survey participants have a pre-tax annual income of under $\$ 45,999$, with $21 \%$ making less than $\$ 11,000$. University employees, meanwhile, earn a median annual income that ranges between $\$ 56,000$ and $\$ 65,999$. The median hourly rate of pay for participants who work off-campus is $\$ 15$, just below living wage figure for Regina. In 2015, almost 22.7\% (a quarter) of Saskatchewan workers earned $\$ 15$ an hour or less (MacEwen, 2016). Seventy percent of those employed possess some form of supplementary employment benefit. About $5 \%$ of those individuals employed off-campus (4.7\%) receive tips, with gratuities averaging $\$ 61.58$ per shift. Table 2 illustrates the median annual pre-tax income by industry of off-campus employment based on survey findings.

Table 2.

Median income by off-campus occupations

\begin{tabular}{|c|c|c|}
\hline Off-campus employment by occupation & $\begin{array}{l}\text { Number of respondents } \\
\qquad(\mathrm{n}=282)\end{array}$ & $\begin{array}{l}\text { Median pre-tax annual } \\
\text { income range }\end{array}$ \\
\hline Construction & 6 & $\$ 16,000-\$ 26,000$ \\
\hline Manufacturing & 2 & Below $\$ 10,999$ \\
\hline Food services \& accommodations & 46 & Below $\$ 10,999$ \\
\hline Transportation and warehousing & 5 & $\$ 11,000-\$ 20,999$ \\
\hline Utilities & 4 & $\$ 11,000-\$ 20,999$ \\
\hline Professional and scientific services & 19 & $\$ 21,000-\$ 35,999$ \\
\hline Education & 31 & $\$ 36,000-\$ 45,999$ \\
\hline Arts, entertainment, recreation & 22 & $\$ 11,000-\$ 20,999$ \\
\hline Public administration & 29 & $\$ 21,000-\$ 35,999$ \\
\hline Management & 5 & $\$ 36,000-\$ 45,999$ \\
\hline Finance and insurance & 14 & $\$ 36,000-\$ 45,999$ \\
\hline Mining, oil and gas extraction & 3 & $\$ 66,000-\$ 75,999$ \\
\hline Other natural resources & 2 & $\$ 36,000-\$ 45,999$ \\
\hline Wholesale and retail trade & 49 & Below $\$ 10,999$ \\
\hline Agriculture & 6 & $\$ 21,000-\$ 35,999$ \\
\hline Health care & 9 & $\$ 11,000-\$ 20,999$ \\
\hline Other & 30 & $\$ 11,000-\$ 20,999$ \\
\hline
\end{tabular}

Workload was also given consideration in the survey. Of the sessional participants, $51.6 \%$ (half) taught three or more classes in an academic year, on average. It was not uncommon (20.7\%) for sessionals to teach a course load equivalent to instructors (approximately six or more classes), but compensated on a per-course basis. There is reason to believe that the ranks of "full-time" sessionals might have expanded due to the introduction of quasi-seniority preference language in the collective agreement around 2006. Depending on rank and experience, this represents an annual wage gap of between $\$ 15,000$ and $\$ 45,000$ per year, assuming comparable teaching loads and using the compensation structure outlined in the respective collective agreement. Instructors, however, are responsible for service-related duties-sessionals are not. 
Survey responses also provide an illustration of the number of jobs held by university employees. Of the $46.1 \%$ of workers employed in more than one job throughout the year, $59.6 \%$ worked three or more jobs. A startling $16.1 \%$ were employed in five or more jobs over the course of a year, and 23.6\% (a quarter) said they were employed in three jobs at the same time. Just under half of the university employees in this survey held permanent positions. Most were employed in a combination of casual and limited-term contracts, representative of the workforce. With these various employment configurations in mind, $31.6 \%$ (a third) of University of Regina employees worked 41 or more hours per week. Some (4.1\%) worked in excess of 60 hours per week.

While most (62.1\%) sessionals taught, on average, only one course at a time, a few managed to teach five or more classes at once. Over half said they would accept a fulltime faculty position at the University of Regina if given the opportunity. Although there is little systematic understanding of sessionals and sessional employment at the university, the survey findings yield valuable insights. Twenty-nine percent said that less than a quarter of their annual income is drawn from sessional lecturer contracts, whereas $32.3 \%$ (almost a third) relies on these stipends for most to a substantial majority of their income. Around 16\% said that all of their annual income comes from sessional employment, reflecting the co-existence of classic and contemporary categories of sessional workers at the university. For this reason, surveys of sessionals as far back as 1999 indicate that compensation topped the list of concerns during negotiations, followed by concerns related to transparent hiring practices and job security (URFA, 1999). Students and sessionals alike recognized the challenges faced by this contingent workforce. As one student participant said of sessionals:

I think that a lot of them are and I think a lot of them aren't [well paid]. Sessional lecturers for example are a good example of people that aren't working with a really strong sense of job security. My dad has his main job with the city but he also works part time in the university as a sessional lecturer. So he does one class every other semester kind of thing, and there's not a lot of security in that. (Student working in the retail industry)

These findings suggest that while professionals lend their expertise to the university by teaching courses as a "classic" iteration of a sessional worker, a significant percentage rely on this type of work as a principal source of income. Still, the University of Regina, like other post-secondary institutions, depends on contingent labour as an important source of course delivery (Nelson \& Dobson, 2015). In fact, the university deploys a higher rate of term and casual academic workers compared to other support staff functions. This is consistent with the adoption of efficiency and cost-cutting business models being deployed by colleges and universities across North America, Europe, and Australia (Standing, 2015; Pocklington et al., 2002), which is made possible by the historically unregulated use of non-permanent academic workers.

Employment trends such as this also threaten the institution of academic freedom for term-based academic workers, since sessional contracts can be cancelled or simply not renewed without cause. Indeed, the full force of the University of Regina's academic freedom language enshrined in the URFA collective agreements only includes activities carried out in the performance of work duties, and for sessionals this excludes research and 
service functions. The improper application of rules governing sessionals is not unheard of; the practice includes the cancellation of contracts, ambiguous appointment letters, and instances of sessional "blacklisting." For these and other reasons, language specific to sessional employment was a focus of the 2014 round of collective bargaining between URFA and the University of Regina. Still, it is important to be mindful that academic freedom-related grievances and information complaints constitute just 22 of the 1,585 total complaints in the last ten years, according to URFA (personal correspondence).

\section{Overtime and Overwork}

In response to anecdotal evidence that students were being asked to work without pay or credit on research projects, a line of survey and interview questions related to unpaid work was developed. A total of 75.5\% (three quarters) of participants admitted to receiving no overtime rate of pay, which is symptomatic of several potential factors: the nature of salaried and term contract positions; a lack of knowledge of existing overtime rates; or, an expectation that employees work overtime without access to the legal or contractual minimum rates guaranteed under the Saskatchewan Employment Act or respective collective agreements. Unfortunately, the precise reason cannot be isolated in the data. The balance of responses identified "time and a half," "double time," or "in lieu" as their respective overtime rates. Employees offered some explanations during the interviews.

Salaried non-academic workers at the university spoke about the seasonal nature of workloads and overtime expectations, which are often based on student recruitment and enrolment demands. APT agreements permit the banking of overtime at a rate of 1.5. In some cases, working unpaid hours is necessary in a context of budget cuts when certain tasks need to get done. Workers even take on these responsibilities when instructed not to by supervisors, as one participant recalled:

We're not allowed to have overtime anymore, we haven't for several months, but our position just requires it because sometimes we have very busy peak times and you just don't get the work done in the work day, so I stay sometimes longer than I should just to get stuff done. Because it has to be done... (Non-unionized support staff)

Some categories of sessionals are required to work unpaid hours in order to complete their duties. As one practice coach remarked:

Fourteen hours per week paid time plus planning, phone calls, emails, assignment review/marking, necessary learning for the instructor equals 16 hours unpaid time as well. Then there are meetings randomly called. It's very difficult to have another job... The faculty is supposed to provide an office to work in but does not.... Personally I want a permanent position, active leadership, and benefits such as pension, vacation pay. (Sessional lecturer)

This reflection is not only about rates of pay and overtime, but also the conditions under which non-permanent academic staff work. Sessionals who teach courses and maintain active research programmes are further disadvantaged by their precarious status within the university. For them, scholarly activity is unrecognized and unpaid, adding another dimension of unseen exploitation. 
Other faculty members, it's a recognized part of their job so when a full-time faculty member publishes a paper, when they do this community work, when they participate on panels for the students' benefit and so on that's a part of the job.... If I eventually get a full-time job maybe some of this will matter but right now it's unpaid [and] unrecognized. (Sessional lecturer)

Facilities management workers offered reflections on the structural problems associated with constrained infrastructure budgets and shrinking staff complements. This, one worker said, has created an atmosphere of overwork during a period of campus expansion. Since 2002, the university's building area has increased by $43 \%$, just as government support for post-secondary education has declined in real terms (University of Regina, 2014). Further cuts were introduced in the 2016-17 budget (Martin, 2016).

Well my boss comes in and says, "When is the last time you cleaned the hallways?" I said, "You've got to make a choice. I have 13 staff but today I've got 3. Do you want to sit on the scrubber? Make a choice."... When I started at the university, like I said, we had close to 90 people there and we had half the campus and we had 6,700 students. We've got 14,000 students now, twice the size of the campus, and some of the buildings we don't clean in those buildings, but guess where they go for lunch? (Custodian)

\section{A Living Wage Employer?}

Nearly 31.8\% (one third) of University of Regina employees possess annual household incomes in excess of $\$ 150,000$ according to survey data. In most University of Regina employee households (85.9\%), there is more than one income earner. About 68.1\% (two thirds) of these employees are living in households earning above the Regina average of \$93,670 (CANSIM Table 111-0009). However, around 20\% of employees occupy households earning less than Regina's living wage. There is a fairly even distribution of individual employee annual income, from $14 \%$ earning below $\$ 10,999$ to $11.3 \%$ making in excess of $\$ 100,000$. About $51.7 \%$ (half) of the sample earn less than $\$ 55,999$, with salary scales ranging between $\$ 46,000$ and $\$ 65,999$ being the most common. By comparison, $64.8 \%$ of the students earn less than $\$ 20,999$ per year.

Salaries and compensation constitute an important aspect of living wage indicators, but employees were also asked to comment on job security and workplace satisfaction. University employees mostly hold positive views of working conditions and compensation. When asked how they would describe their immediate working environment, $58.2 \%$ of respondents answered "very good" to "excellent." Only 16.1\% responded with "fair" or "poor." Pay and benefits were ranked as "good" to "very good" (63.4\%), but only 9.7\% said "excellent." Over 26.9\% (a quarter) would describe their pay and benefits as "fair" or "poor." Another story is told when examining perceptions of job security. A majority of employees, or 52.2\%, are "fearful" or "very fearful" of losing their jobs at the university due to budget cuts or subcontracting. Only $20.9 \%$ said they never think about it.

Members of the APT group were the most fearful (58.3\%) of losing their jobs due to subcontracting and/or budget cuts, followed closely by academic staff (57.2\%), then "others" (45.8\%). Yet APT employees said they were most content with their pay and benefits (84.7\%), with "others" being the least satisfied (67.8\%). This latter category, however, was 
the most likely (87.5\%) to describe their immediate working environment as positive. Academics were the least satisfied with their working environment even though responses were overwhelmingly positive (81\%). Faced with a recent history of layoffs and a looming deficit (Benjoe, 2015), one employee said that he or she was not sure if his or her job was safe. The individual went on to provide a rationale for the institution's financial predicament:

It would be mainly provincial cuts and then they've turned it into a business model, and then that business model is not panning out because there's less students attending, there's less tuition so they're making more cuts to more services. (APT support staff)

According to employees, some units on campus are already short staffed due to attrition, prompting some participants to believe that their employment at the university is secure. This follows in the wake of a voluntary retirement package deal offered by the university in 2014-15. Others, meanwhile, felt confident that the employer valued their services and performance to such an extent that job cuts in these areas would be unimaginable. "I don't think they can afford to let any more people go, or have any more people leave," said a library worker.

During interviews, university employees typically described a sense of pride in their jobs, especially those individuals who were working in a student support capacity. For the most part, the University of Regina and the federated colleges were recognized amongst participants as good employers. This status, survey results illustrate, was earned due to what participants attributed to a fair compensation and benefits package as well as to how they were treated individually at work in what some described as a generally supportive community. But not everyone shared these views.

Sessional interview participants believed that the compromising of the university's academic mission through the increased deployment of precarious academic labour was reason enough to question the University of Regina's place as a top employer in Saskatchewan. Part of this is due to what one individual attributed to the increase in senior administrative positions, not an uncommon, albeit disputed claim amongst academic staff in post-secondary institutions (Usher, 2013):

I mean I think that everybody in the University has been frustrated. I think that whether or not you have a full-time faculty position or you're a precarious worker as part of the academic workforce there's been a disintegration of the academic mission as administrators are hiring more and more of their own that's putting that ratio of administrators to people that are fulfilling the academic mission of the University out of whack.... It's toxic. (Sessional lecturer)

A tenured faculty member echoed this position, recognizing that tensions between faculty and "administration" have led to a deterioration of the quality of work. This problem worsens when the faculty complement falls below what is required to run a successful program. During interviews, academic and administrative support staff expressed concerns about the bureaucratic nature of management and decision making, compromising what could otherwise be a more collegial and effectively managed workplace. This, a student support worker insisted during an interview, has made the institution more 
"businesslike." A library worker, meanwhile, lamented about a poorly constructed "lean" initiative that would have sacrificed employee satisfaction and autonomy for efficiency. Their biggest complaint was that a study was conducted but nothing materialized in what was defined as an "absolute waste of money."

A number of concerns related to dignity and respect in the workplace were also confronted during interviews. Some felt that the university short-changed skilled trades during negotiations by not properly examining comparable private sector rates of compensation. Others, from custodians to student support workers, believed that there persists a culture of disrespect when it comes to a range of support workers represented by CUPE. As Losinger (2016) writes, the "invisible nature of staff employees-whether night time custodians or administrative assistants-means that their working stories are largely absent or non-existent" (p. 154). But even when their work is visible, recognition is not always positive. As support staff participants illustrate, the marginalization of these occupations takes place at the bargaining table, by immediate supervisors, and at the hands of fellow employees.

You snap your fingers and I jump or you're in trouble. It's never what it was meant to be. I'm nobody's fucking servant.... Right now they just shoot from above and get out of the way. It's wrong. It is damn wrong. (Custodian)

\section{Towards a Living Wage University}

Living wage discussions commonly turn to how workers can improve their conditions of employment. As the history of living wages illustrates, popular movements are responsible for driving social policy changes that bring about wage ordinances and improve basic standards of work. Indeed, the exclusion of certain occupations and sectors from economic growth in the 1990 os provoked the formation of living wage movements, and today's Fight for $\$ 15$ and Fairness campaign is premised on organizing for economic transformation (Bush, 2016). But as these movements illustrate, an analysis of living wages must be accompanied by an interrogation of job security, working conditions, and precarious employment.

Over half of the interview participants believe they and others deserve to be making a living hourly wage and annual income, citing benefits to themselves and local communities. Participants also concur that the university and municipalities should be living wage employers, if these institutions are not already. During interviews, participants were asked how these changes should be brought about. Most of the responses gravitated toward human capital models (Becker, 1964) emphasizing educational advancements, networking, labour market experience, and simply finding new or additional sources of employment that pay more as a means of earning a living wage. This approach aligns with the educational spending budget embedded within living wage calculations. "I think what you do is you search out for those employers and opportunities," said one sessional lecturer who is also employed full-time off campus. Becoming a self-advocate and promoting your capabilities in the workplace with superiors was also identified as a means of improving employment conditions.

Other participants believed that the capacity to voice concerns about workplace issues without fear of reprisal should be an avenue for affecting change. The university environment is no different. But, as several participants insisted, employees are often left without 
access to these voice mechanisms. As a former food service employee pointed out, "The biggest barrier to improving standards and conditions of employment is [that] people can't afford to complain or go to court or to fight for their rights." A few interview participants identified unions and collective bargaining as an avenue to lift working conditions and advance toward a living wage. For workers with precarious job security, however, accessing the benefits of these institutions can be challenging. Even within a bargaining unit, by one sessional's account, permanent, tenure-track employees wield greater influence, with precarious workers and their interests being sidelined in the process: "So even within that union that's supposed to account for and advocate against my precarity, I feel like I have a precarious and marginal position. I guess the answer is continue to run the neo-liberal rat race."

Using collective bargaining and union representation to advance the interests of contingent workers possesses limitations. Labour organizations have also been largely unable to stop the growth of contingent academic work, as evidence from both the University of Regina and from Canada's post-secondary sector demonstrates (Dobbie \& Robinson, 2008). Experiences in Canada, the UK, and the US suggest that living wage campaigns hold promise in building bridges between occupations, bargaining units, employee groups, and the various constituencies that define a university community. In this respect a campus living wage movement must concern itself with quality of employment, dignity and respect in the workplace, cost of living, and professional development and identities, as well as bread-and-butter issues like compensation and benefits (Nissen, 2000; Wells, 2016). Since hourly rates of employment and household incomes suggest that most employees are earning a "living wage," the character of work and job security is as important as the level of remuneration. These are also struggles that must move beyond occupational silos, as well as the walls of a particular university. An identification of class and class struggle in this regard is essential (Nelson \& Dobson, 2015; Palmer, 2013). Indeed, the success of living wage campaigns hinges on the capacity of these projects to generate solidarity across communities.

\section{References}

A living wage. (1894). The Economic Journal, 4(14), 365-368.

Ana, L., \& Hall, T. (2015). Organizing migrant workers: The living wage campaign at the University of East London. Industrial Relations, 46(3), 208-221.

Arthurs, H. (2006). Fairness at work: Federal labour standards for the 21st Century. Ottawa, ON: Human Resources Development Canada.

Axelrod, P., Anisef, P., \& Lin, Z. (2001). Against all odds? The enduring value of liberal education in universities, professions and the labour market. Canadian Journal of Higher Education, 31(2), 47-77.

Baldwin, R. G., Chronister, J. L., Rivera, A. E., \& Bailey, T. G. (1993). Destination unknown: An exploratory study of full-time faculty off the tenure track. Research in Higher Education, 34(6), 747-761.

Becker, G. (1964). Human capital: A theoretical and empirical analysis. Chicago, IL: University of Chicago Press. 
Benjoe, K. (2015, August 28). First Nations University of Canada budget deficit leads to layoffs. Regina Leader-Post. Retrieved from http://leaderpost.com/news/local-news/ first-nations-university-of-canada-budget-deficit-leads-to-layoffs?_lsa=0590-4f9b

Burns, R. (2014, January). The adjunct's lament: Even the ivory tower is often solitary, poor, nasty, brutish and short. In These Times, PAGES.

Bush, D. (2016, May 27). Why \$15 matters for Ontario's unions. [Blog post] Retrieved from http://rankandfile.ca/2016/05/27/why-15-matters-for-ontarios-unions/

Canadian Centre for Policy Alternatives - Saskatchewan. (2016). 2016 living wage for Regina and Weyburn. Regina, SK: CCPA-SK.

Carr, S. C., J. Parker, J. Arrowsmith, \& Watters, P. (2016). The living wage: Theoretical integration and applied research agenda. International Labour Review, 155(1), 1-24.

Dobbie, D., \& Robinson, I. (2008). Reorganizing higher education in the United States and Canada: The erosion of tenure and the unionization of contingent faculty. Labor Studies Journal, 33(2), 117-140.

Fairris, D., \& Reich, M. (2005). The impacts of living wage policies: Introduction to the special issue. Industrial Relations, 44(1), 1-13.

Field, C. C., Jones, G. A., Stephenson, G. K., \& Khoyetsyan, A. (2014). The "other" university teachers: Non-full-time instructors at Ontario universities. Toronto, ON: Higher Education Quality Council of Ontario.

Flynn, M. M. (2012). Simon Fraser University: Becoming the first living wage university in Canada.Vancouver, BC: First Call: BC Child and Youth Advocacy Coalition. Retrieved from https://livingwagesfu.files.wordpress.com/2012/10/sfu-living-wageresearch-report.pdf

Gill, R. (2014). Academics, cultural workers and critical labour studies. Journal of Cultural Economy, 7(1), 12-30.

Government of Canada. (2013, December). Income inequality in Canada: An overview. Report of the Standing Committee on Finance. Retrieved from http://www. ourcommons.ca/DocumentViewer/en/41-2/FINA/report-3/

Ivanova, I. \& Klein, S. (2015). Working for a living wage: Making paid work meet basic family needs in Metro Vancouver. Ottawa, ON: Canadian Centre for Policy Alternatives.

Losinger, I. (2016). Solitudes of the Workplace: Women in Universities. Kingston, ON: McGill-Queen's University Press.

Luce, S. (2005). The role of community involvement in implementing living wage ordinances. Industrial Relations, 44(1), 32-58.

MacEwen, A. (2016, May 25). Who earns minimum wage? [Blog post]. Retrieved from http://www.progressive-economics.ca/2016/05/25/who-earns-minimum-wage/

Martin, A. (2016, July 8). University of Regina's balanced budget raises tuition 3.8\%. Regina Leader-Post. Retrieved from http://leaderpost.com/news/local-news/universityof-reginas-balanced-budget-raises-tuition-3-8 
Muzzin, L. (2009, May). Equity, ethics, academic freedom and the employment of contingent academics. Academic Matters, 19-22.

Mysyk, A. (2001). The sessional lecturer as migrant labourer. Canadian Journal of Higher Education, 31(3), 73-92.

Nelson, M., \& Dobson, L. (2015). Precarious employment in Ontario's university sector: Reflections on collective bargaining at Carleton University. Alternate Routes, 26, 200-222.

Newson, J. (2015). Disrupting the "student as consumer" model: The new emancipatory project. In C. Polster \& J. Newson (Eds.) A penny for your thoughts: How corporatization devalues teaching, research, and public service in Canada's universities (pp. 197-212). Ottawa, ON: Canadian Centre for Policy Alternatives.

Nissen, B. (2000). Living wage campaigns from a "social movement" perspective: The Miami case. Labor Studies Journal, 25(3), 29-50.

Noble, D. (2002). Digital diploma mills. New York, NY: Monthly Review Press.

Nolan, D. (2014, August 8). McMaster offers living wage to casual cleaners. Hamilton Spectator. Retrieved from http://www.thespec.com/news-story/4740485-mcmasteroffers-living-wage-to-casual-cleaners/

Noonan, J., \& Coral, M. (2015). The tyranny of work: Employability and the neoliberal assault on education. Alternative Routes, 26, 51-73.

Parker, J., Arrowsmith, J., Fells, R., \& Prowse, P. (2016). The living wage: Concepts, contexts and future concerns. Labour \& Industry: A Journal of the Social and Economic Relations of Work, 26(1), 1-7.

Palmer, B.D. (2013). Reconsiderations of class: Precariousness as proletarianization. In L. Panitch, G. Albo, \& V. Chibber (Eds.), Socialist register 2014: Registering class (pp. 40-62). London, England: The Merlin Press.

Polster, C., \& Newson, J. (2015). A penny for your thoughts: How corporatization devalues teaching, research, and public service in Canada's universities. Ottawa, ON: Canadian Centre for Policy Alternatives.

Rajagopal, I. (2004). Tenuous ties: The limited-term full-time faculty in Canadian universities. Reviews in Higher Education, 28(1), 49-75.

Sharpe, A., Arsenault, J.F., \& Harrison, P. (2008). The relationship between labour productivity and real wage growth in Canada and OECD countries. Ottawa, ON: Centre for the Study of Living Standards.

Spooner, M. (2017). Qualitative research and global audit culture: The politics of productivity, accountability, and possibility. In N.K. Denzin \& Y. S. Lincoln (Eds.), Handbook of qualitative research (5th ed.) (pp. 894-915). Thousand Oaks, CA: Sage.

Standing, G. (2011). Precariat: The new dangerous class. London, England: Bloomsbury Academic.

Standing, G. (2015). A Precariat charter: From denizens to citizens. London, England: Bloomsbury. 
Statistics Canada. (2011). National Household Survey Profile, Regina, CMA, Saskatchewan. Retrieved from http://www12.statcan.gc.ca/nhs-enm/2011/dp-pd/prof/ details/page.cfm $?$ Lang $=\mathrm{E} \& \mathrm{Geo} 1=\mathrm{CMA} \&$ Code $1=705 \&$ Data $=$ Count $\&$ SearchText $=$ regina $\&$ SearchType $=$ Begins\&SearchPR $=01 \& A 1=$ All \&B1 $=$ All \&Custom $=\& T A B I D=1$

Stevens, A. (2014). Call centres and the global division of labor: A political economy of post-industrial employment and union organizing. New York, NY: Routledge.

Pocklington, T., Tupper, T., \& Titley, B. (2002). No place to learn: Why universities aren't working. Vancouver, BC: UBC Press.

University of Regina. (2014, July 2014). University of Regina's operations forecast for 2015-2016. Retrieved from http://www.uregina.ca/orp/assets/budget/operationsforecast/2015-16-of.pdf

University of Regina. (2015a). Academic workforce demographics. Retrieved from https://www.uregina.ca/hr/assets/docs/pdf/reports/2016-09-Academic-WorkforceDemographics.pdf

University of Regina. (2015b). Workforce demographics overview: September 2015. Retrieved from https://www.uregina.ca/hr/reports.html Usher, A. (2013, September 12). Financing Canadian universities: Are administrators to blame? [Blog post]. Retrieved from http://higheredstrategy.com/financing-canadian-universities-are-administratorsto-blame-part-4/

Walsh, J. (2000). Living wage campaigns storm the ivory tower: Low wage workers on campus. New Labor Forum, 6(Spring-Summer), 80-89.

Warme, B., \& Lundy, K. (1988). Erosion of an ideal: The presence of part-time faculty. Studies in Higher Education, 13(2), 201-213.

Wells, D. (2016). Living wage campaigns and building communities. Alternate Routes, $27,235-246$.

Wills, J. (2009). Subcontracted employment and its challenge to labor. Labor Studies Journal, 34(3), 441-460.

Yerema, R., \& Leung, K. (2016). Recognized as one of Saskatchewan's top employers (2017). Retrieved from http://content.eluta.ca/top-employer-university-of-regina

\section{Contact Information}

Andrew Stevens

Faculty of Business Administration

University of Regina

andrew.jr.stevens@gmail.com

Andrew Stevens is an assistant professor in the Faculty of Business Administration at the University of Regina. He also holds an adjunct position in the Department of Sociology. His research focuses on political economy, labour studies, and the sociology of work. Dr. Stevens is the author of Call Centres and the Global Division of Labor: A Political Economy of Post-Industrial Employment and Union Organizing, published by Routledge in 2014. 